\title{
In-situ measurements of sootblower jet impact in a recovery boiler
}

KARI SAVIHARJU, ANDREI KALIAZINE, HONGHI TRAN, AND TONY HABIB

ABSTRACT: Two mill trials were conducted in a recovery boiler at a kraft mill in Sweden using a force measurement probe to examine the performance of a sootblower under different blowing conditions. The results show that at a given distance, the force produced by the sootblower jet increases almost linearly with an increase in lance pressure. At a given lance pressure, the jet force decreases rapidly as the distance increases, retaining less than $10 \%$ of its original strength at a distance beyond $1 \mathrm{~m}$ from the nozzle. The results also suggest that flue gas temperatures in the vicinity of the sootblower have an insignificant effect on sootblower performance, and that the sootblowing jet force exerted on a tube target can fluctuate widely, particularly at a close distance. Force fluctuations are caused mainly by the vibration of the target as it is struck by the jet. The change in jet strength is caused by platen swinging and the tremor of the system that holds the target.

Application: Mills may use this information to improve sootblowing efficiency in their recovery boilers.

$\mathbf{T}$ he efficiency of a sootblower jet in removing deposits in recovery boilers is strongly related to the peak impact pressure (PIP) of the jet. Much work has been done in the past two decades to study jet characteristics and interaction with tubes and deposits. However, due to the harsh environment in the recovery boiler, most studies were performed under well controlled conditions in the laboratory using small scale equipment [1-3] and an entrained flow reactor with compressed air as a blowing medium [4], or by means of analytical modelling and numerical simulations [5,6]. While studies may have been conducted to examine the performance of sootblowers in operating recovery boilers, none has been reported in the literature to date. As a result, theories, as well as experimental and modeling results obtained from laboratory studies with respect to sootblower performance, have never been validated.

There are many differences between the environment in recovery boilers and test conditions used in laboratory studies that make results obtained from the laboratory difficult to apply. These include the use of larger sootblower nozzles in recovery boilers; use of superheated steam (as opposed to compressed air); high flue gas temperature (versus room temperature); continuous transverse/rotational movement of the sootblower lance; greater distance between the sootblower nozzle and the target; vibrations of tubes and boiler structure; presence of tubes/deposits in the sootblower jet path; and background noise, etc. There is, therefore, a need for a systematic study of sootblower performance under recovery boiler conditions.

A collaborative project was initiated by Andritz in late 2007 to examine the performance of sootblowers in-situ, using a jet force measurement system. The work involved design and construction of two force-measurement systems; using the systems to conduct field trials under various sootblowing conditions in recovery boilers at two different kraft pulp mills; analyzing the data obtained from the trials; and using the results to validate the CFDLib-SJT sootblower jet model that has been developed over the past years [5,6]. This paper discusses one of the force measurement systems; the work involved; and the key results obtained from the first two trials.

\section{FORCE MEASUREMENT SYSTEM}

The force measurement system used in the first two field trials was a water-cooled, 4.4-m-long probe mounted rigidly on a heavy steel frame that was bolted onto the floor near the recovery boiler front wall. As shown in Fig. 1, the probe consists of a force transducer mounted at the cold end, a steel rod with a round plate $48 \mathrm{~mm}$ in diameter at the hot end, a water jacket along the probe to protect the steel rod and sensitive elements from the boiler heat, and a data acquisition system. As the sootblower jet hits the round plate, the force exerted by the jet pushes the rod against the force transducer, producing a signal that is continually recorded by the data acquisition system.

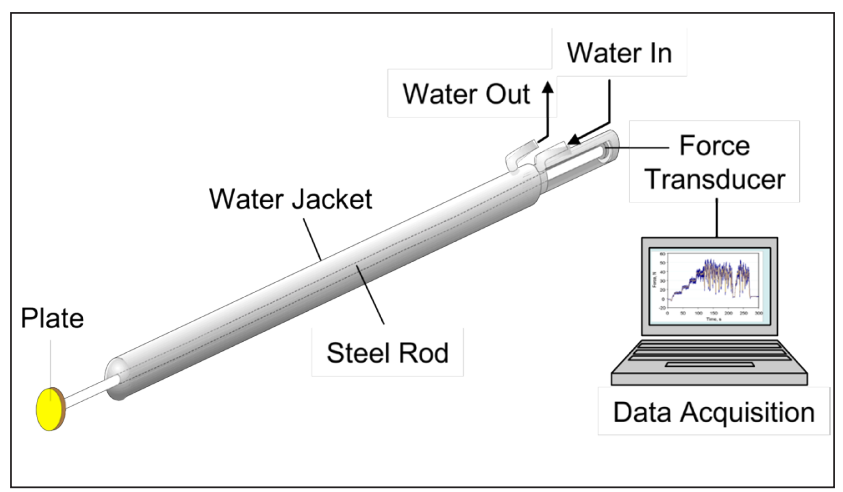

1. Jet force measurement probe. 


\section{TEST PROGEDURES}

\section{Test site}

The trials were conducted on a new recovery boiler equipped with Diamond Power sootblowers at the SCA Packaging mill in Obbola, Sweden. The first trial was in September 2007 and the other in November 2007. In both trials, tests were carried out at the same location on the 11th floor of the boiler, as shown in Fig. 2. The probe was inserted into the boiler through an access door on the front wall near a corner of the boiler. The sootblower that was tested was the first assembly on the right wall of this floor, $3.5 \mathrm{~m}$ from the front wall. At a total length of $4.4 \mathrm{~m}$, the probe was long enough to reach the sootblower nozzle and to measure the jet force at any distance between the nozzle and the front wall. The data were collected at a rate of 1000 times/s. In most tests, however, the

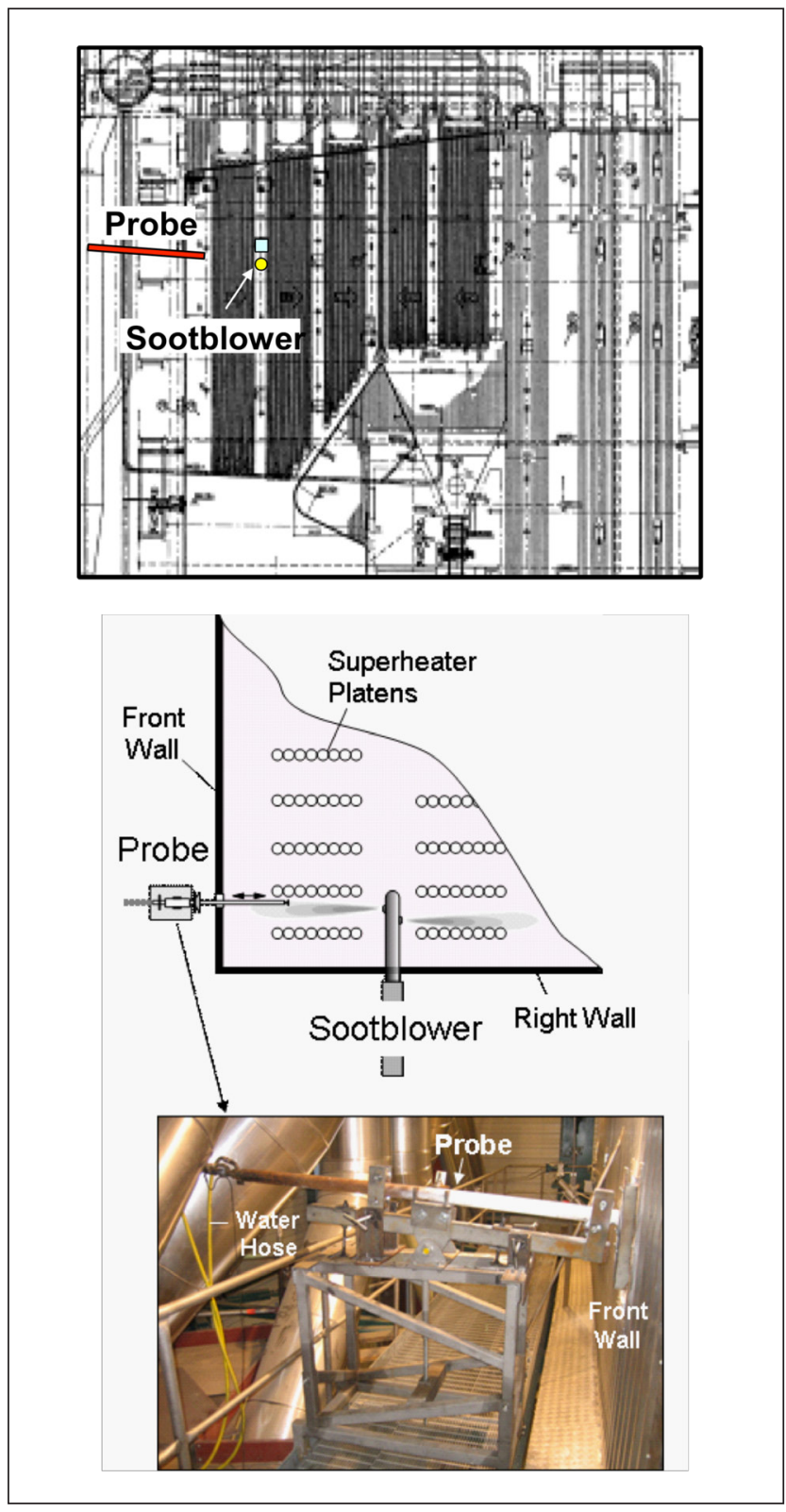

2. Test site and probe assembly. data were filtered every $60 \mathrm{~Hz}$ or higher frequency to minimize variations.

At the time the first trial was carried out, the boiler was about to be commissioned. It was on gas with no black liquor being fired. Since the boiler did not produce its own steam, the superheated steam used for the tests was delivered from a nearly biomass (bark) boiler to the tested sootblower. The flue gas temperature at the test site was therefore low, varying between $100^{\circ} \mathrm{C}$ and $300^{\circ} \mathrm{C}$, and the force measurement probe was free of deposits. During the second trial, the boiler was on liquor, but only at $50 \%$ of its full firing capacity. The flue gas temperature at the test site was still low, about $500^{\circ} \mathrm{C}$ to $540^{\circ} \mathrm{C}$, although it was much higher than during the first trial

\section{Test procedures}

Two types of sootblowing tests were performed: stationary sootblowing and running sootblowing.

\section{Stationary sootblowing tests}

In these tests, the round plate of the probe was first aligned, as perfectly as possible, with one of the sootblower nozzles along its jet centerline. The sootblower was then locked in that position so that it did not move or rotate. The sootblowing steam at a set lance pressure was then turned on for 10 to $100 \mathrm{~s}$ while the force exerted by the sootblower jet on the round plate of the probe was continually measured. The same procedures were used for all tests at different lance pressures and distances from the nozzle. The lance pressure was in creased stepwise (every 2 bars), while the distance was increased by moving the probe along the jet centerline closer to or further away from the nozzle.

\section{Running sootblowing tests}

The procedures were similar to those in stationary sootblowing tests, except that the sootblower was in motion (rotating and moving in-and-out) as it is normally operated. Since the probe position was fixed, the round plate was hit by the jet only intermittently for a very short period of time, usually less than $0.1 \mathrm{~s}$.

\section{Test site}

It is important to point out that the round plate of the probe must be well aligned with the sootblower jet centerline in order for it to receive the maximum available force from the jet. During stationary sootblowing tests, the alignment was done by pushing the probe plate to touch the sootblower nozzle (zero distance) as shown in Fig. $\mathbf{3}$, and then withdrawing it to a required distance along the jet axis. Since this procedure was not possible while running sootblowing tests due to high temperatures and nozzle movement, the alignment was performed using a high-temperature inspection camera However, the limited view of the camera made the alignment task difficult, particularly at locations near the nozzle where probe vibrations were excessive. For each test condition, measurements were repeated several times to establish the mag- 


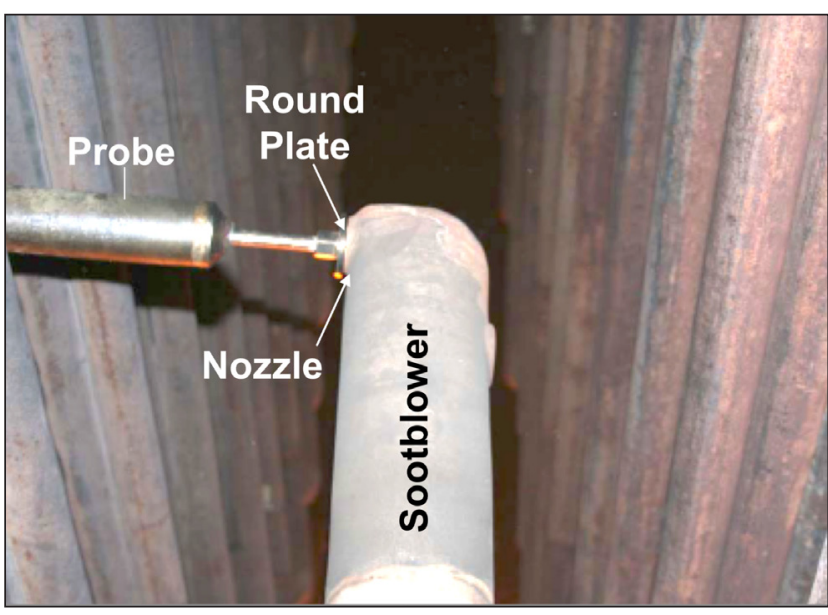

3. Probe-nozzle alignment prior to a stationary sootblowing test.

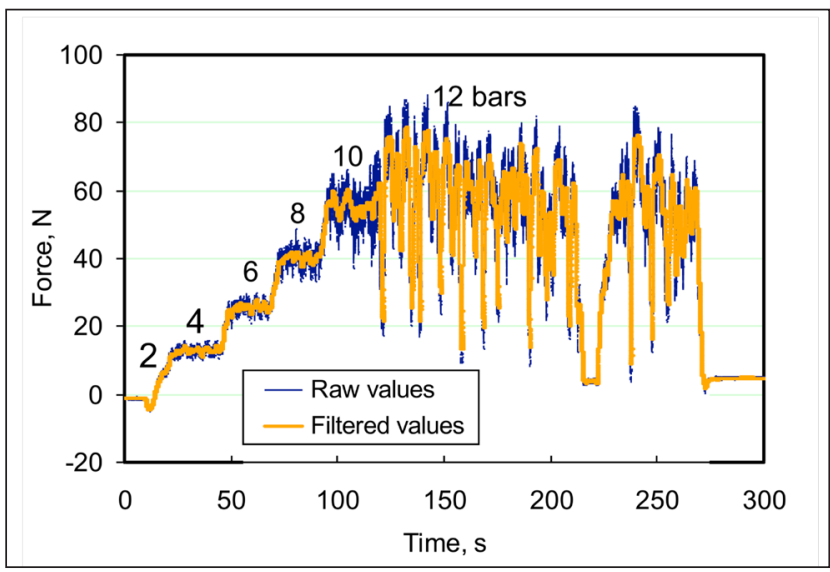

4. Force recorded by the probe during a stationary sootblowing test at $750 \mathrm{~mm}$ from nozzle.

nitude of errors caused by misalignment.

In addition to misalignment, friction between the steel rod and the water jacket can also be a source of measurement errors. The error caused by friction was found to be less than $\pm 10 \mathrm{~N}$ during the first trial when the boiler was not burning black liquor and the probe was free of deposits. During the second trial, the boiler was on liquor and thus the probe was often covered with a layer of deposits which increased the friction between the steel rod and the water jacket. When this happened, the probe was taken out and cleaned, and the test was repeated.

\section{ANALYSIS OF RESULTS}

\section{Stationary sootblowing tests}

These tests were carried out at a fixed lance pressure between 2 and 12 bars (gauge) and at a distance between $300 \mathrm{~mm}$ and $1050 \mathrm{~mm}$ from the nozzle. Figure $\mathbf{4}$ is a typical response for the probe at $750 \mathrm{~mm}$ from the nozzle. It clearly shows that the jet force increased with a step increase in lance pressure, and that the force fluctuated widely with amplitude that increases with increasing lance pressure, particularly at 12 bars.

Figure 5 shows the average forces measured at $750 \mathrm{~mm}$ from the nozzle plotted against lance pressures. The relation-

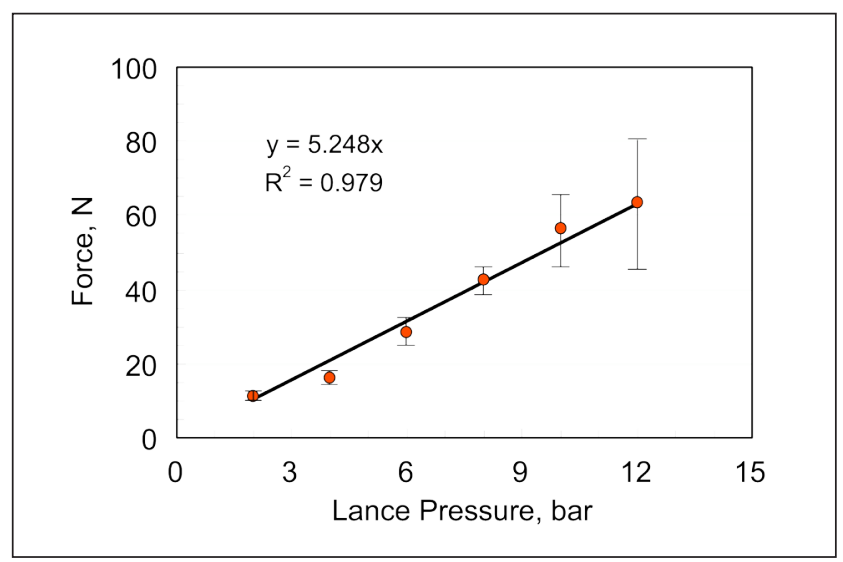

5. Averaged force values at $750 \mathrm{~mm}$ from the nozzle as a function of lance pressure.

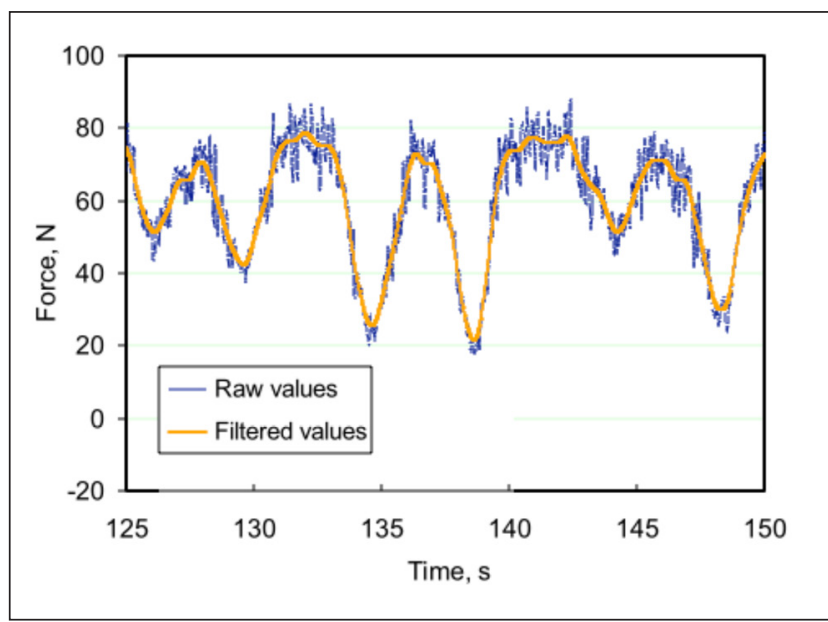

6. Same as Fig. 4, but between 125 and 150 s. Force fluctuations are likely a result of superheater platen swinging (lance pressure $=12$ bars).

ship appears to be linear. Similar results were obtained at other distances.

Examining the data fluctuation shown in Fig. 4 at higher temporal resolutions reveals that the fluctuation was likely caused by different types of vibration induced on the force measurement probe. Figure 6 , for example, shows the same data as Fig. 4, but only in the range between 125 and $150 \mathrm{~s}$. Two types of vibration can be seen here: one has a low frequency, about $0.2 \mathrm{~Hz}$ or once every 4 to $5 \mathrm{~s}$, and a high amplitude ( 25 to $60 \mathrm{~N}$ ), and the other has a high frequency (about $5 \mathrm{~Hz}$ ), but a low amplitude ( 5 to $10 \mathrm{~N}$ ).

During both the first and second trials, the superheater platens were found to swing badly whenever they were struck or "pushed" by the sootblower jet. The duration T, in seconds (s), for a superheater platen to make one swing can be estimated as:

$$
\mathrm{T}=2 \pi \sqrt{\frac{\mathrm{L}}{2 \mathrm{~g}}}
$$

where $\mathrm{L}$ is the platen length in $\mathrm{m}$, and $g$ is gravitational accel- 


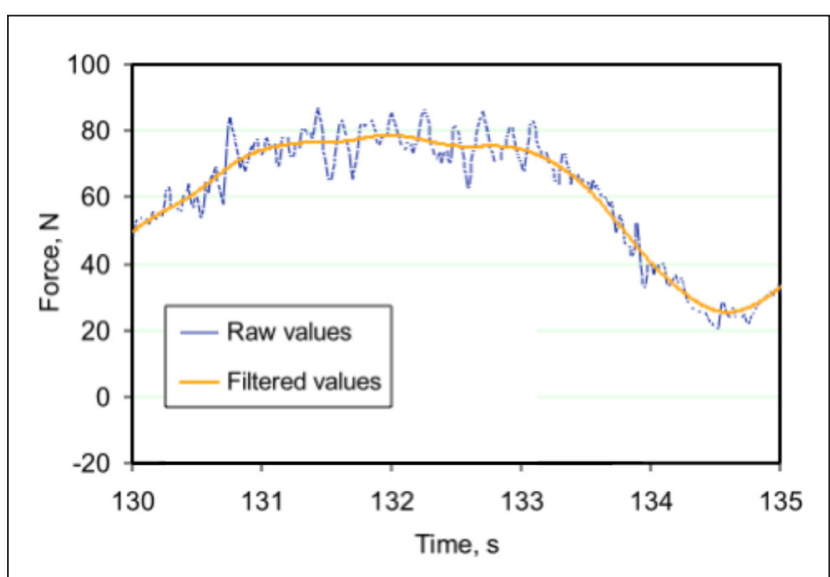

7. Same as Figs. 4 and 6, but between 130 and 135 s. Force fluctuations are likely a result of probe assembly vibration (lance pressure $=12$ bars).

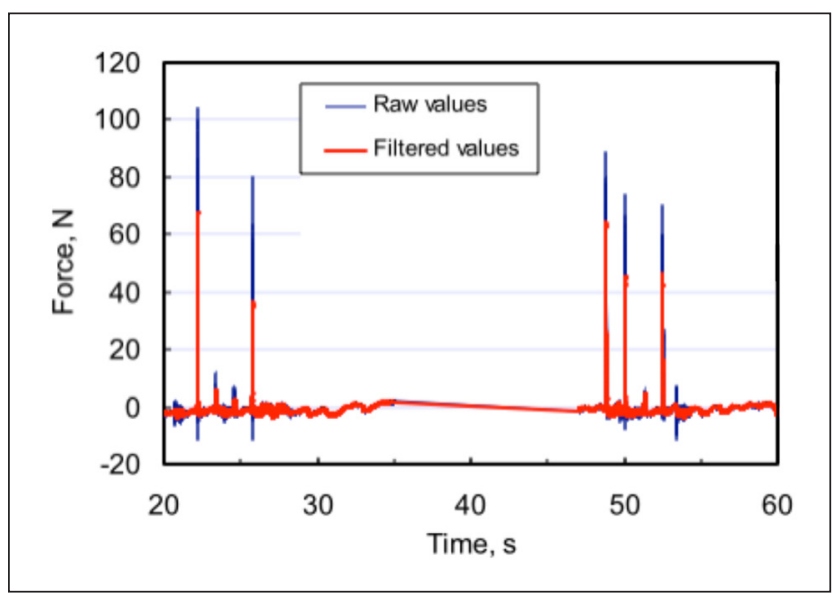

8. Instantaneous force registered during a running sootblowing test at 750 mm distance and 10 bar lance pressure.

eration, $9.81 \mathrm{~m} / \mathrm{s}^{2}$. For this recovery boiler, $\mathrm{L}=14 \mathrm{~m}$, and thus, $\mathrm{T}=5.3 \mathrm{~s}$, which is almost the same as the fluctuation period shown in Fig. 5. This implies that the most probable cause of the force fluctuation is platen swinging resulting from jet impingement. Platen swinging alters the space between platens, thereby affecting the jet trajectory and strength.

Figure 7 shows the same data as Figs. 4 and 5, but at a much higher data temporal resolution between 130 and 135 s. In contrast to the previously described fluctuation caused by platen swinging, this high-frequency low-amplitude fluctuation was found to be independent of probe distance and thus was probably caused by the vibration of the probe assembly itself.

\section{Running sootblowing tests}

In these tests, the sootblower lance was in motion at a rotational speed of about $25 \mathrm{rpm}$. The jets from the front and rear sootblower nozzles sequentially hit the probe round plate for a short period of time, producing spikes of force as shown in Fig. 8. Strong spikes presumably resulted when the jet was well aligned with the probe, while weak spikes occurred

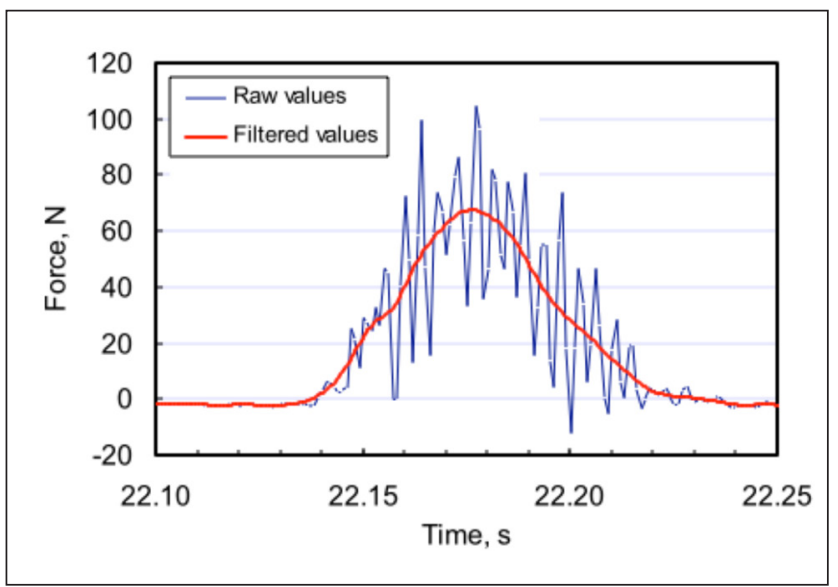

9. Same as Fig. 8, with a much higher temporal resolution.

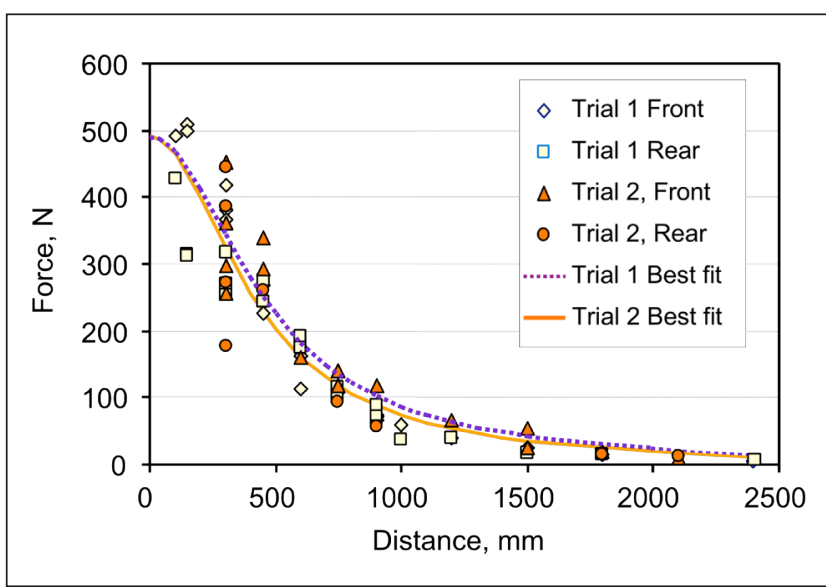

10. Jet force measured for all tests at 10 bar lance pressure during running sootblowing tests in trials 1 and 2 as a function of distance from nozzle.

when the jet-probe alignment was poor. Since these spikes were sequentially produced by the front and rear nozzle jets, they occurred at an equal time interval corresponding to one half of the lance rotation time of $1.2 \mathrm{~s}$.

Examining the data in a greater temporal resolution reveals that each spike lasted about $0.1 \mathrm{~s}$ and consisted of periodic high-frequency and high-amplitude fluctuations (Fig. 9). The frequency of fluctuations in this case did not change with probe location, suggesting that the fluctuation was caused by the natural frequency of the probe assembly, which included the load cell, the round plate, and the steel rod. Furthermore, since these high-frequency high-amplitude fluctuations were not observed during the stationary sootblowing tests (Fig. 7), they were probably caused by the probe's vibration in response to the sudden impact of the rotating sootblower jet.

The data fluctuations were filtered using a low-pass filtering technique to minimize the effect of probe vibration and movement on force signals. The filtered signals were used to estimate the jet force and other parameters. Figure 10 plots the averaged maximum (peak) force values obtained from all running sootblowing tests during both the first and second 


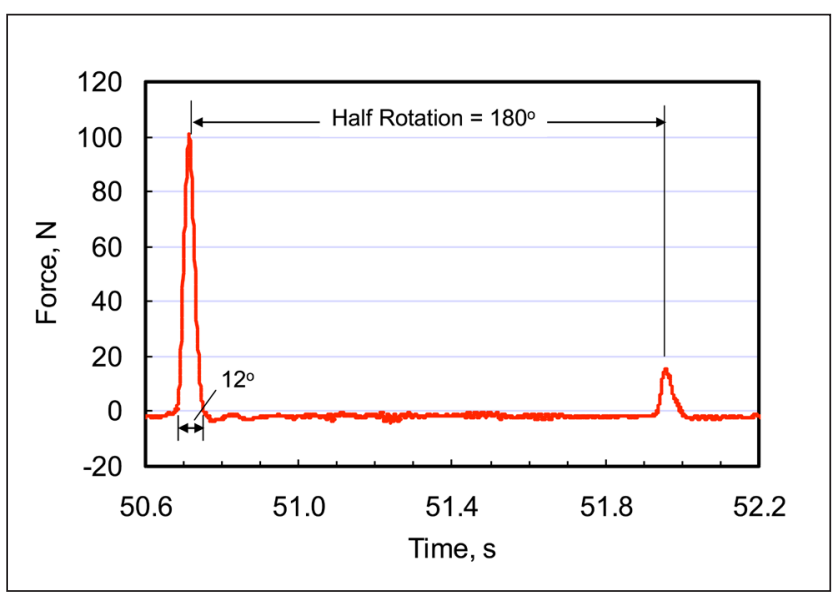

11. Filtered force signal in a period that includes two subsequent jet blasts during a running sootblowing test, at 10 bars lance pressure and $750 \mathrm{~mm}$ distance.

trials at 10 bar lance pressure as a function of probe distance from the sootblower, along with the best fit curves for results obtained from these two trials. It clearly shows that the jet force diminishes rapidly with an increase in distance from the nozzle, retaining less than $10 \%$ of the original force value at a distance beyond $1 \mathrm{~m}$ from the nozzle.

As mentioned earlier, the flue gas temperatures in the boiler during these two trials were significantly different: $100^{\circ} \mathrm{C}$ to $300^{\circ} \mathrm{C}$ during the first trial and $500^{\circ} \mathrm{C}$ to $540^{\circ} \mathrm{C}$ during the second trial. The best fit curves in Fig. 10 are close to each other and the difference between them is within the error of measurements. This implies that flue gas temperature in the range tested may not have any significant effect on sootblower performance.

The results obtained from these field trials are consistent with those obtained from laboratory studies $[1,2,3]$ and numerical modeling $[5,6]$, supporting the validity of experimental and numerical work.

\section{Jet spreading}

During running sootblowing tests, the jets from two opposite nozzles, front and rear, periodically hit the probe, producing sharp force spikes at an equal time interval of about $1.2 \mathrm{~s}$. Figure 11 shows the force profile in a period covering two subsequent jet blasts during a running sootblowing test. Since the jets are blown in opposite directions, the time interval between the blasts corresponds to a half rotation $\left(180^{\circ}\right)$ of the lance tube. The first spike was much stronger than the second spike, suggesting that it resulted from a better jet-probe alignment. In this case, the spike duration was $0.08 \mathrm{~s}$ and the time between two spikes was $1.2 \mathrm{~s}$. This means that the jet spreads over an angle $\theta$ of $0.08 \times 180^{\circ} / 1.2=12^{\circ}$.

Note that, for a given system, the jet spreading angle $\theta$ is fixed. The spike duration registered by a fixed probe is expected to be independent of the distance from the nozzle and be equal to $\theta / 360^{\circ} \times \mathrm{T}$, where $\mathrm{T}$ is the time required for one lance rotation.

Comparing the amplitude of spikes registered at different

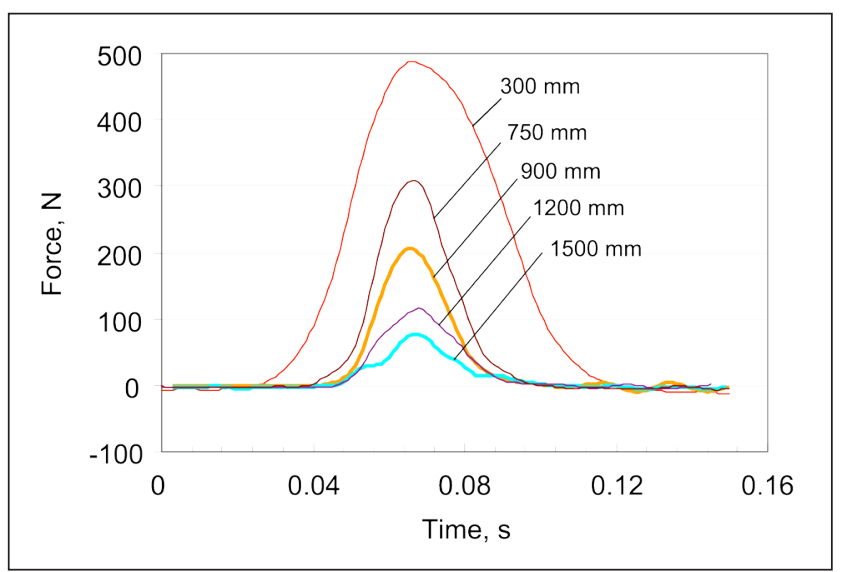

12. Force profiles at different distances from the nozzle. Lance pressure range from 16 to 18 bars for all tests.

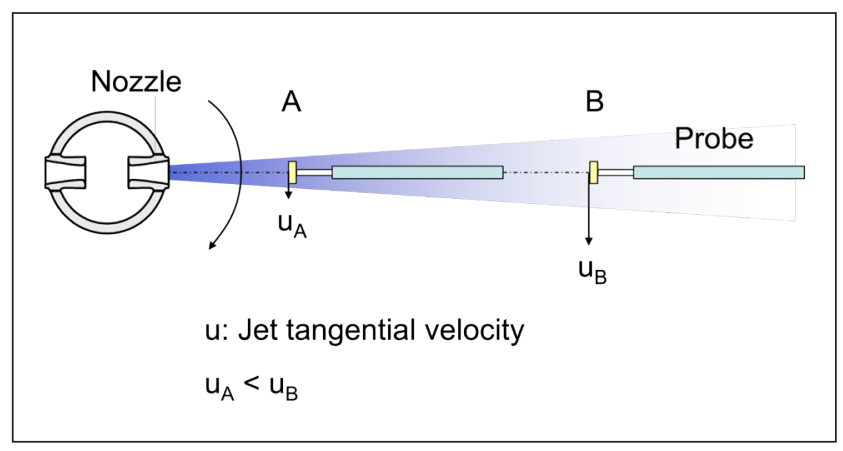

13. Change in linear velocity of jet with distance from nozzle. Linear velocity at location $A$ is lower than at location $B$.

distances from the nozzle shows that the amplitude decreased with an increase in distance (Fig. 12). At a distance farther than $900 \mathrm{~mm}$ from the nozzle, the spike duration was about the same, while at a closer distance, $<750 \mathrm{~mm}$, the spike duration was longer. These results are plausible; since the tangential velocity of the jet centerline is lower at locations closer to the nozzle, it requires a longer time for the centerline of the jet (where the impact pressure is highest) to sweep through the round plate of the probe, as schematically shown in Fig. 13.

This is interesting since it suggests that at a location closer to the nozzle, not only is the target exposed a stronger jet force, but it is also exposed for a longer period of time.

\section{CONCLUSIONS}

This work was the first to systematically examine the performance of sootblowers in-situ. The work was performed on a new recovery boiler using a specially-designed probe to measure the force exerted on it as by a sootblower jet under various blowing conditions. The following conclusions may be made:

- Jet force increases linearly with an increase in lance pressure. However, this may be true only within a limited range of lance pressure.

- At a given lance pressure, the jet force diminishes markedly with an increase in distance from the nozzle. At a distance farther than $1 \mathrm{~m}$ away from the nozzle, the jet 
exerts only $10 \%$ of its original force on the same target.

- At a location closer to the nozzle, not only is the target hit by a greater jet force, it also is exposed for a longer period of time.

- Flue gas temperature has an insignificant effect on sootblower performance.

- The force exerted by a sootblower jet on a target can fluctuate widely, particularly near the nozzle. Force fluctuations are caused mainly by the vibration of the target as it is struck by the jet, the change in jet strength caused by platen swinging, and the tremor of the system that holds the target.

The results obtained in this study are consistent with those obtained from laboratory studies and numerical modeling.

\section{DEDICATION}

This paper is dedicated to Kari Saviharju of Andritz who initiated the project and helped bring it to fruition. Mr. Saviharju died of cancer in December 2008.

\section{NOTES}

A previous version of this paper was awarded Best Paper at the 2010 International Chemical Recovery Conference (ICRC).

\section{ACKNOWLEGEMENTS}

The authors also wish to acknowledge Tero Karttunen and Markku Tanttu of YTI Research Centre for their assistance with probe design and construction of the probe, together with Lars-Gunnar Magnusson of Andritz, for their leading role in the collection of field data. Thanks also due to the SCA Obbola mill for providing the test site and help during the trials. This work was conducted as part of the research program on "Increasing Energy and Chemical Recovery Efficiency in the Kraft Process," jointly supported by the Natural Sciences and Engineering Research Council of Canada (NSERC) and a consortium of the following companies: AbitibiBowater, Alstom Power, Andritz, Babcock \& Wilcox, Boise Paper Solutions, Carter Holt Harvey, Celulose Nipo-Brasileira, Clyde-Bergemann, Diamond Power International, Domtar, DMI Peace River Pulp, Fabria, Georgia Pacific, International Paper, Irving Pulp \& Paper, Metso Power, MeadWestvaco, StoraEnso Research, and Tembec. TJ

\section{LITERATURE CITED}

1. Jameel, M.I., Cormack, D.E., Tran, H.N., et al. Tappi J. 77(5): 135(1994).

2. Kaliazine, A., Cormack, D.E., Ebrahimi-Sabet, A., et al. J. Pulp Pap. Sci. 25(12): 418(1999).

3. Mao, X., Tran, H.N., and Cormack, D.E., TAPPI J. 84(6): 68(2001).

4. Pophali, A., Eslamian, M., Bussmann, M., et al. TAPPI J. 8(9): 4(2009).

5. Tandra, D., Kaliazine, A., Cormack, D.E., et al. Pulp Pap. Canada 108(5): 43(2007).

6. Emami, B., Bussmann, M., Tran, H.N., et al., Int. Chem. Recovery Conf., TAPPI PRESS, Atlanta, GA, USA, 2010, Conf. CD.

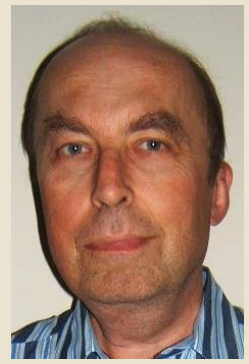

Kaliazine

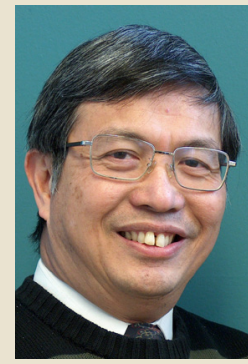

Tran

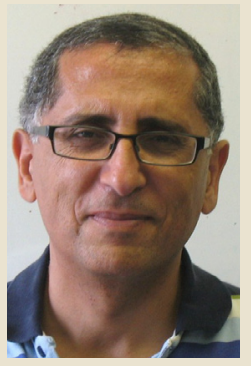

Habib
The most difficult aspect of this work was to design and construct force measurement equipment. The equipment had to withstand the harsh environment in an operating recovery boiler and reliably measure the sootblower jet force in-situ. We addressed this challenge through our combined expertise in the area.

This work proved to validate our laboratory and computer modelling work that was performed over the past decade. The most surprising finding was that jet strength can also be affected by superheater platen swinging.

Mills may use this information to improve soot- blowing efficiency in their recovery boilers. Our next step is to conduct trials in another recovery boiler to see if we can reproduce the results.

Saviharju (deceased) was R\&D director with Andritz, Helsinki, Finland. Kaliazine is research associate and Tran is the Frank Dottori professor of pulp \& paper engineering in the Pulp \& Paper Centre and Department of Chemical Engineering \& Applied Chemistry at the University of Toronto, Toronto, ON, Canada. Habib is A-S-H R\&D supervisor with Diamond Power International Lancaster, OH, USA. Email Tran at hongi.tran@utoronto.ca. 